Viso - Cadernos de estética aplicada Revista eletrônica de estética

ISSN 1981-4062

No 19, jul-dez/2016

http://www.revistaviso.com.br/
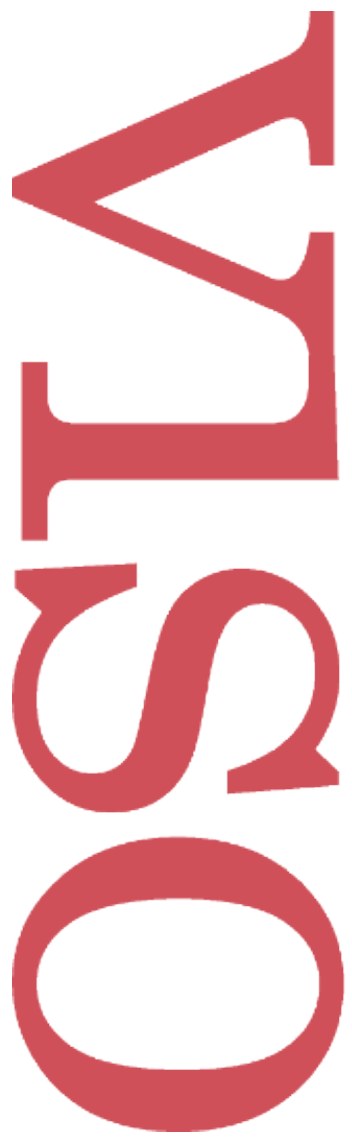

\title{
A arte da crítica: Conversa entre um ator japonês e um crítico brasileiro \\ Patrick Pessoa
}




\section{RESUMO}

A arte da crítica: Conversa entre um ator japonês e um crítico brasileiro

Este diálogo filosófico entre um ator japonês e um crítico teatral brasileiro incorpora à sua própria forma a tese de fundo defendida pelo crítico brasileiro: a de que a crítica teatral é uma forma de arte.

Palavras-chave: Lukács - Hegel - Barthes - crítica teatral

\section{ABSTRACT}

The Art of Criticism: Conversations between a Japanese Actor and a Brazilian Critic

This philosophical dialogue between a japanise actor an a brazilian critic embodies in its own form the main thesis defended by the brazilian critic: he sees the theatrical critic as a form of art.

Keywords: Lukács - Hegel - Barthes - theatrical critic 


\section{PESSOA, P. "A arte da crítica: Conversa entre um ator japonês e um crítico brasileiro". In: Viso: Cadernos de estética aplicada, v. X, n. 19 (jul-dez/2016), pp. 70-92.}

DOI: $10.22409 / 1981-4062 / v 19 i / 231$

Aprovado: 13.11.2016. Publicado: 28.12.2016.

(C) 2016 Patrick Pessoa. Esse documento é distribuído nos termos da licença Creative Commons Atribuição-NãoComercial 4.0 Internacional (CC-BY-NC), que permite, exceto para fins comerciais, copiar e redistribuir o material em qualquer formato ou meio, bem como remixá-lo, transformá-lo ou criar a partir dele, desde que seja dado o devido crédito e indicada a licença sob a qual ele foi originalmente publicado.

Licença: http://creativecommons.org/licenses/by-nc/4.0/deed.pt_BR

Accepted: 13.11.2016. Published: 28.12.2016.

(C) 2016 IPatrick Pessoa. This document is distributed under the terms of a Creative Commons Attribution-NonCommercial 4.0 International license (CC-BY-NC) which allows, except for commercial purposes, to copy and redistribute the material in any medium or format and to remix, transform, and build upon the material, provided the original work is properly cited and states its license.

License: http://creativecommons.org/licenses/by-nc/4.0/ 
Pensar [denken] e agradecer [danken] são palavras que, em nossa língua, tem uma única e mesma origem. Quem investiga o seu sentido encontra-se no campo semântico de: 'recordar' [gedenken], 'ser cuidadoso' [eingedenk sein], 'memória' [Andenken] e 'devoção' [Andacht].

Paul Celan

\section{Nota preliminar}

Conheci Ryunosuke Mori, um ator japonês que de imediato me lembrou muito o Chishû Ryû, numa viagem a Tóquio, em 2008. Depois de uma apresentação de "Na selva das cidades" com elementos do butô, mais tarde ressignificada pelo Aderbal Freire-Filho em sua montagem carioca, fui cumprimentar os atores e descobri que Mori falava português. A mãe dele, como fiquei sabendo mais tarde naquela mesma noite, tinha nascido em Bastos, no interior de São Paulo, e voltara para o Japão por causa de um casamento arranjado com o pai de Mori, que ela só veio a conhecer no dia das bodas. O modo como ele se apropriou do papel de Shlink, praticamente sem se mover durante as quase três horas de espetáculo, construindo cada mínimo gesto com um máximo de intensidade, mas sem se identificar empaticamente com o personagem, me parece até hoje a melhor interpretação da absurda capacidade de resistência daquele velho comerciante malaio, modelo do self made man que conseguiu vencer "na selva das cidades" justamente por ter transformado a própria pele em uma carapaça e a própria opinião em uma mercadoria como outra qualquer. É sempre uma revelação quando um ator consegue traduzir corporalmente (e não psicologicamente) aquilo que importa em um personagem. Em nossa conversa no camarim após o espetáculo, tomei a liberdade de perguntar se poderia entrevistá-lo sobre aquela subversiva apropriação nipônica do pensamento de Brecht. Para minha surpresa, ele me respondeu que naquela noite mesmo estava livre. "Adoro falar português", me disse. O português dele era quase perfeito, só tinha aquele " $r$ " retroflexo típico do interior de São Paulo, e acabamos ficando até altas horas falando de tudo um pouco. Com relação a Brecht, ele tinha opiniões bem radicais. Mori defendia que, sem a arte do ator japonês, o conceito brechtiano de Verfremdung seria irrealizável na prática. Mais que isso: para ele, todo teatro ocidental moderno só se tornaria compreensível à luz das inovações cênicas surgidas nos mimos primitivos da Coreia do Norte, que haviam sido introduzidas no Japão em fins do século XIX pelo mestre Hiroda e posteriormente levadas para a Europa por um de seus discípulos, ensaiador na companhia de Strindberg. Mesmo sem concordar inteiramente com aquele ator extraordinário - por que os mimos primitivos da Coreia do Norte seriam mais importantes para a dramaturgia ocidental do que o teatro de marionetes da China, muito mais antigo? -, fui envolvido pelo que ele falava e pelo gosto do saquê quente que ele me serviu ao longo daquela noite memorável. Afinal, uma hipótese não precisa ser verdadeira para ser interessante. E Mori tinha um brilho mordaz e zombeteiro no fundo dos olhos que dava um interesse peculiar a cada uma de suas palavras.

Anos depois, em 2015, ele veio ao Rio apresentar um texto apócrifo de Brecht no CCBB e voltamos a nos encontrar. Notei que o tempo havia sido generoso com ele, sintoma de 
uma vida feliz. Num fim de tarde de caipirinhas no Restaurante do Círculo Militar na Praia Vermelha, tentei explicar a ele como a minha visão da crítica havia mudado desde nosso encontro em Tóquio, quando a mistura improvável de Heidegger e Brecht ainda estava desequilibrada, dando a meus textos um viés mais existencialista que materialista. Como, àquela altura, estava dando um curso intitulado "A arte da crítica" no Espaço SESC, no âmbito do 3o Encontro Questão de Crítica, a conversa girou basicamente em torno das ideias que eu estava tentando articular, nem sempre com clareza.

Reproduzo abaixo, de memória, o diálogo que tivemos naquele dia. Tomei a liberdade de corrigir os eventuais erros de português de Mori. Achei que a singularidade de seu pensamento não precisava ser caricaturada linguisticamente, o que é talvez recurso válido no caso de um personagem cômico, mas não quando se trata de um amigo que, cordialmente, se dispôs a pensar junto comigo e a tornar menos obscuras para mim mesmo algumas questões persistentes.

M: No Japão, quando sai uma crítica, o elenco se reúne para ler junto, em voz alta. A gente forma uma roda no meio do palco e cada um lê uma frase, tentando imitar a cara e o tom da pessoa que escreveu. Em geral, a gente chora de rir. Como é que alguém que não faz teatro pode falar de teatro? Os textos dos nossos críticos parecem paródias das paródias daquele escritor argentino estupendo.

P: O que ficou cego ou o outro?

M: O que ficou cego, acho. Existe inclusive um antigo provérbio chinês que diz mais ou menos o seguinte: "Quem sabe, faz. Quem não sabe, ensina. Quem não sabe ensinar, ensina a ensinar. E quem não sabe nem ensinar a ensinar, escreve crítica".

P: Sempre achei que esse provérbio era árabe... Mas vocês riem até quando os críticos afetam a bilheteria dos espetáculos?

M: Isso não acontece. Há pelo menos uns oito jornais de grande circulação só em Tóquio. Cada um com seu próprio crítico. Uma andorinha só não faz verão, como vocês dizem. Sozinho, nenhum crítico tem o poder de interferir significativamente nas bilheterias. Aliás, é assim em todo lugar. Aqui é diferente?

P: É, um pouco. No Rio a gente só tem um jornal de grande circulação.

M: E qual é o nome? Pravda? 
$\mathrm{P}:($ risos) Mais ou menos.

M: E a Internet? Vocês não têm umas revistas virtuais? Lá no Japão tem um monte. Confesso que não costumo ler. Os textos são longos demais, mas parece que o nível é bem melhor. Aliás, você não escrevia para uma?

P: Escrevo ainda. A gente tem um grupo bem interessante de críticos, pessoas de quem gosto muito. Mas, se for para rir, acho melhor você não ler.

M: Eu jamais riria de você, meu caro. Em todo caso, não pelas costas.

P: Que bom. Embora adore aquele chiste do Oscar Wilde, que dizia achar uma falta de educação dizer na cara de alguém algo que você pode dizer pelas costas, acho hoje em dia que, pelo menos no nosso meio teatral, precisamos aprender a dizer sinceramente o que pensamos.

M: Isso nem sempre é fácil. Os artistas costumam ser muito suscetíveis.

P: Mas é preciso aprender a lidar com isso, aprender a ouvir numa boa. Por exemplo, achei muito tosca essa prática de vocês de se reunirem para rir das críticas. Quase me senti ofendido. Se pensar é, em alguma medida, generalizar, é preciso não exagerar. Ou a gente acaba caindo nessas generalizações babacas que infelizmente fazem o maior sucesso. Assim como há japoneses e japoneses/

M: Acho lamentável quando alguém me julga baseado em estereótipos culturais/

$P$ : há críticos e críticos. "O" crítico não existe. Como sempre, a riqueza está nas diferenças, nas variações. (Pausa.) Não sei por que, lembrei daquela tua interpretação do Shlink.

M: Deve ser porque o conceito de "hunimi", ou "variação sutil", é a alma do butô, que eu tive que praticar muito para fazer aquele trabalho.

P: E valeu a pena, pode acreditar.

M: Você acha mesmo? Em Tóquio não foi nada bem recebido. Teve um crítico que escreveu que a minha voz não era adequada ao personagem. Outro escreveu que não fazia sentido encenar no Japão uma peça escrita por um alemão sobre uma Chicago que ele sequer conhecia. E um terceiro ainda disse que montar uma peça que Brecht escreveu com 22 anos de idade era um desperdício de tempo e dinheiro, já que "Na selva das cidades" era apenas um texto de juventude, ruim e incompreensível, incompatível com o talento do Brecht maduro. 
P: Difícil de engolir.

M: Por essas e outras é que só nos resta rir... Quem são eles para dizer qual é a voz "correta" de um personagem que eu estudei quase um ano para interpretar?! Ou para dizer que um texto é "ruim" e "incompreensível"? Ou para afirmar que a encenação de um clássico estrangeiro "não tem sentido" só porque eles não se esforçaram o suficiente para entender a proposta?!

P: Eu sei do que você está falando. Que bom que em Tóquio vocês podem rir sem medo desses cagadores de regra. Aqui pega mal. Sempre dizem que é ressentimento dos artistas por não terem sido elogiados. Por isso, a maioria sequer reage às asneiras que saem sobre suas peças. Optam pelo silêncio. Com o tempo, vão perdendo a fé no diálogo com os críticos. E isso acaba contaminando os diálogos entre os próprios criadores. É muito raro que um diretor ou um autor ou mesmo um ator diga para o outro o que realmente pensou de um trabalho...

M: Esse exercício é de fato muito importante. É verdade que em Tóquio não temos muito diálogo com os críticos, mas entre nós é outra coisa. Faço questão de ouvir com calma o que os meus colegas viram num trabalho meu. E, quando vou ver o trabalho deles, me esforço para construir um discurso que vá além do "gostei, não gostei".

P: O problema é que, aqui, as relações de poder são bem complicadas. Entre atores, por exemplo, falar sinceramente coisas que firam um colega pode fechar as portas para futuros trabalhos. E, no caso dos críticos, é ainda mais grave. Uma crítica ruim no nosso Pravda pode não apenas inviabilizar financeiramente um espetáculo, pode também impedir que ele seja convidado para os festivais de outros centros importantes. E pode até fechar as portas para os editais de fomento público. É que são sempre os mesmos poucos nomes ocupando as posições de poder.

M: Que merda.

P: É. Mas isso tudo não tem nada a ver com a crítica, pelo menos não como a entendo.

M: Como assim? Acabei de te contar o que alguns dos principais críticos de Tóquio escreveram sobre a nossa "Selva". O fato de um crítico conhecido ter escrito não implica que o que ele escreve é necessariamente uma crítica?

P: De forma alguma. O renome não pode ser a única forma de legitimação. Do contrário, seríamos obrigados a gostar de tudo o que faz sucesso, que vende, que "sai bem", como dizem os nossos garçons. Acho fundamental pensar em outros critérios. Antes que a "mão invisível do Mercado" nos esgane de vez...

M: "Que nada seja dito natural, para que nada seja dito imutável". 
P: O velho Brecht tem razão. A legitimidade é uma construção social como qualquer outra, que obedece a uma rede complexa de condicionamentos, às vezes espúrios. Propaganda, conformismo, preguiça, hábito, bajulação. No caso da "crítica", com muitas aspas, o fato de textos muito curtos servirem de "guia de consumo" ou de "papel de bala" é a principal origem de sua legitimidade, a principal razão de seu alcance social.

M: Crítica como papel de bala? Bela imagem! Mas isso não pressupõe que a arte tenha se tornado uma mercadoria como outra qualquer?

P: Você conhece neste mundo alguma coisa que não seja transformada em mercadoria quase instantaneamente?

M: A minha arte. (Pausa longa.) Brincadeira. Sei muito bem que nem a minha arte está imune à mercantilização. Nada está. Pelo menos por enquanto.

P: "Que nada seja dito natural, para que nada seja dito imutável".

M: É isso aí. Você entende agora por que no Japão os artistas não levam a crítica a sério?

P: Talvez. Mas vocês acham mesmo que essa é uma boa forma de resistir ao império da mercadoria?

M: Pra gente funciona. Pelo menos nos divertimos coletivamente com textos que individualmente poderiam nos destroçar. É foda empregar tanto esforço na construção de um trabalho e depois ver que ele simplesmente não foi compreendido. Mesmo quando são positivas, essas críticas, até por serem breves demais, sempre nos dão a impressão de terem sido escritas às pressas, sem o trabalho e o cuidado que nós próprios temos ao montar os nossos espetáculos.

$\mathrm{P}$ : Acho que isso tem muito a ver com a estrutura do jornalismo em geral. O camarada vê a peça hoje e amanhã o texto já tem que ser publicado. Sair do forno, como dizem aqui.

M: Isso não é desculpa!

P: É verdade. Mas, sinceramente, o riso, o desprezo e mesmo a indiferença pela crítica me parecem uma estratégia pueril, se não conformista. Em primeiro lugar, porque não mudam o status quo que se alimenta dessa crítica e que goza cinicamente com o rebaixamento da arte a uma mercadoria como outra qualquer. Em segundo lugar, porque não mudam a crítica. Uma melhora no nível da crítica poderia, por que não?, transformar as demandas do público. Isso para não falar das preocupações estéticas dos próprios artistas. Ninguém cria a partir do nada. Não existe texto sem contexto. Se você quer saber a minha opinião, que eu teria uma certa vergonha de confessar se você não fosse 
meu amigo, acho que o nível da produção artística de uma cidade, de um país, está diretamente ligado ao nível de sua crítica.

M: Isso me soa idealista demais. Como diria Brecht, o buraco é mais embaixo... Uma transformação da relação dos artistas com a crítica, ou mesmo da própria crítica, seria só uma gota no oceano.

P: Às vezes, basta uma gota para fazer o oceano transbordar.

M: Aí já não é nem mais idealismo, é delírio mesmo! (Risos)

$\mathrm{P}$ : Em todo caso, mesmo que este trabalho esteja fadado ao fracasso, ou justamente por estar fadado ao fracasso, ele é absolutamente necessário. E, pelo menos aqui no Rio, com um grupo pequeno de pessoas tentando praticar a crítica de um outro jeito, e com um grupo de artistas percebendo a importância dessa interlocução, as coisas já começaram a mudar.

M: Mas e o público? Quem lê essas novas críticas? Muita gente?

P: Por enquanto não. E acho importante, pelo menos por enquanto, essa não ser uma preocupação central. Sabe aquela imagem da "mensagem na garrafa" que fica flutuando por aí até ser encontrada num momento propício por alguém que se dispõe a decifrá-la?

M: Acho ruim a ideia de "mensagem".

P: Foi só uma imagem.

M: Só uma imagem?! Não tem nada mais importante do que uma imagem precisa! Mas concordo que produzir com os olhos nas possíveis preferências dessa entidade abstrata que se costuma chamar de "grande público" é um péssimo ponto de partida. Imagina se os artistas fizessem isso!

\section{P: E como fazem!}

M: Alguns, não todos. Eu não faço. Ou pelo menos tento não fazer. Odeio a ideia de que "o cliente tem sempre razão". Quando o gosto do freguês determina a nossa produção, é o fim da possibilidade da criação, do novo. Os fregueses só costumam gostar do que já conhecem, do que não demanda nenhum esforço. Os fregueses só querem emoções fugazes. O que o nosso Brecht chamava de "empatia"...

P: Concordo, com a ressalva de que, para mim, nem todo espectador é um freguês.

M: Claro que não. Se fosse assim, a arte já tinha morrido há muito tempo. 
P: O que vale para você como artista vale para mim como crítico. Se você não quer tratar os teus espectadores como fregueses, e fregueses um pouco burros, tão fáceis de agradar quanto de enganar, eu também não vou tratar os meus leitores como pessoas dotadas de uma "compreensão média", incapazes de ler textos mais longos, mais reflexivos. Sabia que nos jornais eles proíbem até mesmo palavras consideradas difíceis?! Vou tratá-los como eu gostaria de ser tratado.

M: E como você gostaria de ser tratado?

P: À base de uma caipirinha de caju tão boa quanto esta aqui... (Risos. Os dois brindam.) Tudo bem se eu for um pouco ridículo?

M: "Todas as cartas de amor são ridículas". Não foi isso que disse aquele teu tio?

P: Como eu gostaria de ser tratado? (Pausa.) Como um parceiro, um interlocutor numa conversa potencialmente infinita. Dessas que não têm hora para acabar.

M: Tipo esta aqui?

P: Dessas que começaram antes da gente chegar, sei lá quando, na Grécia, na Mesopotâmia, na China, na puta que pariu, não importa, e que vai continuar depois que a gente for embora.

\section{M: Hegel numa hora dessas?}

P: Eu gostaria de ser tratado como alguém que não precisa saber nada específico para sentar na mesa, muito menos Hegel! (Risos.) Como alguém que só quer mesmo pensar junto, seguir as pegadas que o outro deixa na areia. Sentir junto. Como alguém que está aberto para ouvir o outro, a princípio sem ficar julgando. Qual é a importância de concordar ou discordar? Como alguém que acredita que a realidade é tão rica, tão múltipla, tão complexa, tão caótica, que acha meio ridícula a ideia de uma perspectiva verdadeira. Como alguém que quer ouvir o outro, desde que o outro não seja dogmático, não esconda a sua experiência pessoal atrás do manto de uma pretensa objetividade e de um discutível saber. Como alguém que leu num livro de bolso com as páginas meio amareladas que "a única perspectiva falsa é aquela que pretende ser a única". Como alguém que, embora duvide de uma verdade absoluta, aprendeu com o tempo que sempre dá para pensar-sentir melhor se deixando contaminar pelos olhares dos outros. Aproximação, convivência, não é disso que se trata? Como alguém que não opõe autonomia a diálogo, que sabe por experiência própria o quanto uma outra perspectiva é capaz de enriquecer a nossa. Como alguém que aposta que ouvir o outro não é perder a própria voz. Como alguém que sente que falar sobre uma obra não tem nada a ver com julgar, argumentar e convencer. Como alguém que só quer que the mostrem alguma coisa que ele próprio não viu, ou que apenas pressentiu sem conseguir formular. Como 
alguém que goza com as pequenas descobertas, que vê qualquer obra como um potencial livro dos prazeres. Como alguém que...

M: Mas peraí! Eu perguntei como você gostaria de ser tratado por quem escreve uma crítica. E tudo o que você está dizendo me lembra muito mais o modo como eu gostaria que os espectadores dos meus espetáculos se sentissem tratados...

P: No fundo, não vejo nenhuma diferença entre os leitores das minhas críticas e os espectadores de uma obra teatral.

M: Não é possível! Isso implicaria afirmar que não há diferença entre a experiência de um espetáculo e a experiência de um texto crítico!

P: Por que você se espanta? O ideal da crítica, para mim, é funcionar como uma nova apresentação de um espetáculo. Não dizem que cada apresentação teatral é sempre única, diferente das anteriores, e que essa seria uma distinção fundamental entre o teatro e as outras artes?

M: Dizem. Com exceção talvez da performance...

P: Pois então. Por que um texto crítico não pode ser pensado como um outro tipo de apresentação de uma obra teatral? O fato de ser diferente, e de se valer do recurso da prosa, ou da narrativa da experiência singular do crítico, nem seria assim tão original frente a muito do que a gente vê nos palcos hoje em dia. O caráter épico do teatro brechtiano, como você sabe, contaminou boa parte da produção contemporânea.

M: Porra! Explica melhor isso aí. Estou gostando, mas...

P: Quando falam que a crítica é a memória do teatro, que a crítica serve como registro desses fenômenos fundamentalmente efêmeros que são as apresentações de uma obra teatral, acho que é isso no fundo que querem dizer. A crítica só pode sobreviver aos espetáculos que lhe servem de ponto de partida e provocação para o pensamento quando abre mão de ser um "registro objetivo", quando assume a si mesma como uma espécie de "reconfiguração subjetiva".

M: Se não me engano, é isso que defendem os devotos de um impressionismo selvagem no comentário das obras. O que também não acho bom, porque aí a obra deixa de ser o réu num julgamento e se torna puro pretexto para associações quase sempre delirantes que não têm nada a ver com o que materialmente foi trazido à cena. Detesto quando usam uma obra de arte como mera ilustração para falar de "temas" que poderiam ser trabalhados de forma muito mais consistente em outros lugares. Num livro de filosofia, por exemplo. Quem faz isso pode até achar que está fazendo jus à "profundidade" da 
arte, mas a impressão que sempre me fica é que a obra em si, com sua riqueza e linguagem específicas, é apenas usada como uma escada que logo é abandonada.

P: Concordo, abaixo à arte como ilustração de ideias preexistentes! Mas acho que essa tua objeção toca num ponto mais complicado: a oposição que propus entre registro objetivo e reconfiguração subjetiva não é muito precisa. A dicotomia sujeito-objeto é só uma dessas heranças da filosofia ocidental que impregnou a nossa linguagem a tal ponto que fica difícil pensar sem ela. E pensar com ela também. Sendo japonês, tenho certeza de que você dispõe de uma gramática melhor para dar conta desse fenômeno...

M: Talvez, nunca parei para pensar nisso direito.

P: Em todo caso, o que eu estou dizendo não tem nada a ver com "impressionismo". O que há de mais objetivo no mundo é o fato de que toda realidade já sempre se mostra no âmbito de uma interpretação, de uma perspectiva, de um recorte. Não é possível ver sem os próprios olhos.

M: “Não é possível pular a própria sombra”, já dizia o meu caro Hegel.

P: A turma do contra sempre vai querer dizer que essa interpretação é "subjetiva". Ou pior: vai querer dizer com aquele sorrisinho no canto da boca típico dos lógicos que (Imita a voz superior dos acadêmicos aos quais se refere.) a proposição de que tudo é subjetivo contém uma contradição performativa, já que em seu gesto reivindica para si mesma uma universalidade que é recusada por seu teor.

M: Faz sentido...

P: Claro que faz, é uma maneira de ver até bem popular, princípio tanto para o objetivismo mais tacanho quanto para o relativismo mais cínico. Mas quando eu falo em "reconfiguração subjetiva", não estou negando a possibilidade de um critério que, mesmo não sendo universal e necessário (ou objetivo no sentido clássico), é ainda assim passível de ser compartilhado.

M: Que critério é esse?

P: O critério da "integração". Lê aqui embaixo."

M: Embaixo da mesa?

P: Não. Na nota de rodapé.

M: Essa conversa tem nota de rodapé? 
P: Por que não? Toda conversa tem. Ou poderia ter. E essa pode.

Pausa enquanto Mori lê.

M: Agora me diz o que você vê de interessante nisso. Pra mim, talvez por conta desse português mais erudito, fica um pouco difícil de acompanhar.

P: Gosto demais dessa reflexão do Barthes sobre o conceito de crítica. Mas como nem tudo que ele diz tem a ver com a minha visão, vou recortar o que me interessa: a ideia de que uma crítica não tem como tarefa julgar a adequação de uma obra à realidade, ou de uma obra a certos padrões poéticos previamente existentes e pretensamente universais. A crítica tem que tentar entender a obra nos seus próprios termos - e não nos termos do crítico ou de qualquer manual do que seria um "teatro bem feito". Trata-se de entender, ou melhor, de fornecer uma interpretação possível do "ideal da obra", de seu discurso, de seu princípio articulador, de sua proposta, daquilo que dá alguma unidade aos seus elementos, alguma inteligibilidade ao modo como foram justapostos.

M: Supondo que a obra tenha uma unidade... A turma do teatro pós-dramático recusa justamente essa exigência.

P: Não concordo. O que eles recusam é a ideia de que o princípio organizador seja o múthos aristotélico, a trama, o enredo, um princípio de causalidade que encontraria no texto dramático a sua raiz. Mas seria impensável uma obra que não tivesse alguma unidade, quero dizer, uma obra cujos elementos fossem justapostos de forma totalmente arbitrária. Até a fragmentação mais radical, o acaso e a arbitrariedade, quando despontam, obedecem a algum discurso que vê neles um caminho expressivo mais interessante que a linearidade. Quando falo em unidade, portanto, estou falando em termos bem modestos, nada prescritivos. Em todo caso, ando há um bom tempo amadurecendo a ideia de que a atualidade da Poética de Aristóteles depende da possibilidade de pensá-la como uma teoria da recepção, como uma reflexão sobre a crítica, mais do que como uma teoria da produção. É que, por menos unidade que uma obra tenha, a crítica de algum modo há de produzir um "enredo" ou uma "narrativa" que tente integrar os elementos da montagem segundo a experiência temporal do crítico, que, por conta da matéria com a qual trabalha, a prosa, só pode reconfigurar esses elementos diacronicamente.

M: Mas para isso não bastaria entrevistar os realizadores? Perguntar diretamente a eles quais seriam suas intenções?

P: Os realizadores, e me corrija se eu estiver errado, nunca têm um controle absoluto sobre a reverberação de suas obras, sobre as múltiplas possíveis camadas que elas podem ter. Dá uma olhada aí embaixo de novo. ${ }^{2}$ 
Pausa enquanto Mori lê.

M: Bonito isso!

P: Também acho. O fato de ultrapassar "tragicamente" a intenção de seus realizadores implica que uma obra só se completa no seu encontro com o público. Em certo sentido, com cada espectador. Por isso, o Schlegel, camarada que foi fundamental na minha formação, costumava dizer que a crítica não tem nada a ver com um juízo sobre a obra, sendo antes "o método de seu inacabável acabamento". No polo oposto dessa visão, o mais característico dos juízes da arte é justamente tomarem a obra como pronta e acabada antes de sua recepção, como algo que não teria nada a ver com eles. Os juízes fingem que não são coautores da obra, como se pudessem vê-la de fora, de modo puramente passivo. Até hoje, esses juízes da arte (que nos jornais costumam atender pelo nome de "críticos") têm em Pôncio Pilatos a sua maior inspiração: lavam as mãos diante do réu (a obra!), querem se manter puros, objetivos, imparciais, e muitas vezes chegam a evitar o contato com os artistas.

M: É que nós somos contagiosos! (Risos)

P: Mas é claro que há exceções, mesmo nos jornais.

M: Mas então quer dizer que, para além daquelas razões políticas sobre as quais conversamos mais cedo, a tua recusa dos "críticos-juízes" também têm motivações, por assim dizer, estéticas.

\section{P: Com certeza!}

M: E como é que você reconhece, assim concretamente, a diferença entre um juízo e uma crítica?

P: Normalmente, é fácil. São dois os sintomas principais dessa doença que é a "compulsão ao juízo". O primeiro é bem material: está no uso indiscriminado de adjetivos. X é "bom", Y é "ruim", Z é "sutil", A teve uma atuação "irretocável", B fez uma "bela iluminação" e assim por diante. Nos juízos se manifesta um paradoxo curioso: por mais que haja uma pretensão de objetividade, de falar sobre a obra sem sujar as mãos, sem assumir o fato de que a história da recepção é constitutiva e constituinte da própria obra, raramente as descrições são objetivas. Parece mania, mas basta ler uma dessas resenhas de jornal para ver como os substantivos não suportam a solidão dos campos de algodão: precisam sempre vir de mãos dadas com um adjetivo, por mais esdrúxulo que seja. E, claro, quanto menos essas indigestas damas de companhia vêm acompanhadas por descrições substantivas do que viu o juiz, mais impressionista, arbitrário e dogmático fica o todo. 
M: Daí a importância do "nome do crítico", não é mesmo? Ele tem o direito de usar os adjetivos mais delirantes, sem a menor necessidade de desenvolver melhor o seu raciocínio, porque disporia de uma autoridade, de um olho que os outros não têm. $O$ nome do crítico, assim como o seu pretenso saber, também se tornou uma mercadoria...

P: Sem dúvida. Por isso ouvir o que é falado é sempre mais importante do que saber quem fala. Se as obras têm relativa autonomia com relação aos seus criadores, a crítica também precisa ter.

M: E qual seria o segundo sintoma?

P: É o que alguns pesquisadores da Universidade de Boston chamaram de CLD ou "check-list disease". Começou nos anos 1950 com as donas de casa norte-americanas que não conseguiam mais ir ao supermercado sem uma lista de compras - nos casos mais graves, a lista era sempre a mesma - e, por um desses processos difíceis de explicar, acabou se alastrando pelas redações dos jornais. Aqui no Brasil, a maior parte dos "juízos de jornal" deriva a sua forma de um estágio bastante avançado de CLD. Em vez de considerarem cada espetáculo nos seus próprios termos, ordenando seu discurso sobre os elementos cênicos de acordo com a ênfase singular que cada espetáculo lhes dá segundo o princípio unificador de que falamos há pouco, os nossos jornalistas partem de uma estrutura invariável: falam primeiro se o texto do espetáculo é "bom" ou "ruim", às vezes contextualizando em uma ou duas linhas quem foi o seu autor e a época em que foi escrito (e em certos casos realçando a "pertinência" ou a "atualidade" dos temas abordados); depois falam da direção, que pode ter sido "competente" ou "equivocada" ou mesmo "inexistente"; depois consideram a "beleza", "feiura", "adequação" ou "funcionalidade" da iluminação, dos cenários, dos figurinos e da trilha sonora (quase sempre nessa ordem, como se esses elementos não passassem de adereços um tanto quanto supérfluos ou puramente ornamentais) e terminam com chave de ouro, dedicando uma ou duas linhas a cada "estrela" do espetáculo, os atores, cujo trabalho é reduzido a um adjetivo apenas, no máximo dois.

M: Pelo que você está dizendo, então a CLD é a verdadeira causa da compulsão à adjetivação. Tendo em vista a estrutura rígida e a brevíssima extensão das resenhas de jornal, esse elenco de adjetivos vai ter emprego garantido por muito tempo. Te ouvindo falar desse jeito, acho ainda mais legítimo o riso com que recebemos as críticas no Japão. CLD! O Toshiro vai adorar o conceito.

P: Críticas não! Juízos, Mori, juízos! Mas esqueci de mencionar a marca mais gritante desses juízos de jornal: as estrelinhas que julgam o espetáculo como um todo de acordo com uma quase inesgotável lista de adjetivos.

M: Que são? 
P: "Excelente", "Ótimo", "Bom”, "Regular", "Ruim".

M: Crítica como papel de bala. Agora entendi. Bastam esses cinco adjetivos que o freguês do jornal nem precisa ler o texto. Por menor que seja, por mais que os editores e jornalistas se esforcem para facilitar seu pensamento e sua linguagem, sempre vai ser mais do que o freguês precisa para escolher o programinha de sábado à noite, antes da pizza.

P: Outro paradoxo: quanto mais concessões os jornalistas fazem a esse "leitor médio", mais leitores eles perdem, já que menos leitores se dispõem a formar.

M: Mas então você acha que o jornal como plataforma é incompatível com a crítica?

P: Hoje em dia acho. Mas nem sempre foi assim. Houve um passado em que os jornais davam mais espaço à reflexão e os resenhistas de teatro não subestimavam a inteligência dos seus leitores. E também não acho que seja assim em todos os lugares. Rio de Janeiro e Tóquio são apenas dois exemplos, mas quero crer que em alguns lugares a crítica também comparece mais assiduamente nos jornais. Em São Paulo, por exemplo, o nível da discussão já é bem melhor, com mais intercâmbio entre o jornal e a universidade, com mais abertura para outros tipos de formação que não a do "jornalista puro sangue".

M: Em todo caso, dizem que logo logo os jornais impressos vão acabar...

P: Isso infelizmente não é tão promissor quanto poderia ser. Esse modelo de "crítica" como juízo, como exercício dogmático e impressionista da própria "autoridade" e, no final das contas, como papel de bala, já contaminou vários blogueiros das novas gerações. $\mathrm{E}$ temo que, dada a função que desempenha no mercado da arte, ainda vá durar mesmo quando não houver mais nenhum jornal. Nem o nosso Pravda!

M: "Que nada seja dito natural, para que nada seja dito imutável". Já disse isso hoje, né?

P: Umas oitocentas vezes.

M: É que está ficando tarde. Mas antes de ir embora, queria ter uma noção mais clara dessa outra crítica aí que você defende. Acho que já entendi muito bem o que ela não é, mas queria entender melhor o que ela é. Em poucas palavras, se possível.

P: Em poucas palavras? Tipo resenha de jornal? Porra, acabei de dar um curso inteiro sobre o conceito de crítica que acho mais interessante e você me pede para resumir? Sacanagem. 
M: Não precisa ser preciso, é só para eu ter uma ideia. Prometo que não vou mais te interromper.

P: Assim não tem graça. Mas vamos lá. Na verdade, acho que já disse o mais importante. Lembra do conceito de "integração" do Barthes? Então: se a tarefa do crítico, como ele diz, não é julgar se as opções cênicas do artista que ele analisa estão corretas nem "descobrir" a verdade da obra, mas sim "cobrir" o máximo possível com a sua própria linguagem (que inclui o momento histórico que está vivendo, as suas referências teóricas e as experiências pregressas que teve em outros espetáculos e na vida em geral) a linguagem da obra que ele toma como ponto de partida, temos um primeiro critério para definir a crítica em sentido estrito. Ela tem que integrar e ressignificar o máximo possível de elementos, chamando a atenção para a sua necessidade e a sua articulação. Por mais aparentemente isolado que esteja cada elemento de uma encenação, a crítica precisa tornar visível como esses elementos se constelam.

M: Mas peraí: isso não é o que tentam fazer os jornalistas quando cedem à CLD e tentam dar conta de todos os nomes da ficha técnica?

P: De forma alguma. O fato de que eles falam de cada elemento separadamente, sempre na mesma ordem, e dando um destaque excessivo aos nomes dos artistas (outra mercadoria!) responsáveis por cada item da ficha técnica, mostra justamente que eles não são capazes de articular esses elementos, de constelá-los segundo o princípio unificador de cada obra singular. Se fossem capazes de fazer isso, a ordem de apresentação dos elementos no texto crítico seria absolutamente variável, os nomes dos artistas não precisariam necessariamente ser mencionados e sobretudo haveria elementos que, embora presentes em uma encenação, sequer precisariam ser considerados pelo crítico, já que não seriam especialmente relevantes no âmbito daquele recorte particular.

M: Então, se estou entendendo o que você está querendo dizer, mais importante do que a ideia de "integração" ou de "constelação" é a ideia de "princípio unificador".

P: Sem dúvida. Isso que estou chamando de "princípio unificador" em um texto crítico funciona assim como um ímã que atrai para si todos os elementos de um espetáculo, tornando possível a sua visualização como produto de um discurso específico.

M: Mas esse "discurso específico", que para você e para o teu camarada Schelling não se confunde com a "intenção do autor", estava lá antes, à espera de ser descoberto, ou é produzido pela crítica?

P: Ih, acho que o Japão já se ocidentalizou. Você está me perguntando se o princípio unificador é objetivo ou subjetivo. Nem uma coisa nem outra! Os gregos falavam do "ser" como um "antes que só se mostra depois". O Barthes, naquele rodapé, falava que a 
"crítica consiste em dizer com atraso" aquilo que de algum modo a obra já havia dito. O que é curioso é que nem esse "antes" nem esse "já dito" podem ser lidos como fatos brutos independentes do trabalho de interpretação. Em outras palavras: ao reconfigurar a obra a partir de um princípio unificador, ou de uma questão central, o que a crítica faz é tornar visível na obra algo que sem dúvida já estava lá, mas que jamais teria aparecido e ganhado uma formulação precisa se não fosse o trabalho do crítico. Se faz sentido para quem leu a crítica, se não soa arbitrário, decerto é porque já estava lá. Mas estava lá em estado latente, como uma semente esperando pelo jardineiro que a faria florescer. Sem o jardineiro, essa flor jamais teria vindo à luz.

M: O crítico é então uma espécie de jardineiro? Mas e o encenador? Essa metáfora não seria válida também para ele, sobretudo quando traz à cena textos clássicos?

P: Acho que sim, por que não? Uma montagem de um texto preexistente que não é simultaneamente um ensaio sobre esse texto não me interessa. $E$ mesmo que o texto seja novo ou sequer seja o elemento desencadeador do espetáculo, sem primazia hierárquica, ainda assim cada espetáculo precisa ser lido como uma tomada de posição num debate mais amplo sobre a história da arte. Nesse sentido, todo bom encenador tem muito de crítico. Ou de jardineiro. Mas como o crítico opera sobre a obra do encenador, talvez seja possível pensá-lo como um jardineiro de segunda ordem, ou um jardineiro de jardineiros. Afinal, ao trazer à luz virtualidades presentes na obra que nunca teriam vindo a ser, o crítico de algum modo potencializa a obra, torna visíveis para os próprios realizadores camadas que eles não haviam percebido.

M: "Ninguém pode pular a própria sombra". Acho que essa também já disse hoje. Mas é por isso é que a gente depende do olhar do outro.

P: Inclusive, acho que os diálogos mais fecundos entre críticos e encenadores se dão justamente quando o encenador potencializa o olhar do crítico através de sua obra e quando o crítico potencializa a obra do encenador através de seu recorte singular.

M: A crítica como um modo de potencializar a obra, de intensificar o seu alcance, de multiplicar as suas camadas, gosto muito dessa ideia.

P: Eu também. E o mais curioso é que ela está lá nos primeiros românticos alemães, dos quais o teu brilhante amigo Hegel tanto zombou.

M: Qual o problema? Hegel tinha razão. A sua. Schlegel também. Que importa que as suas posições sejam contraditórias? Uma vez li no prato de um restaurante de Kioto o seguinte haikai: "O oposto de uma pequena verdade é uma falsidade. O oposto de uma grande verdade é outra grande verdade". 
$P$ : Esse haikai vale para as relações entre as obras. E também para as relações entre distintas críticas de uma mesma obra.

M: Mas se a crítica é uma forma de intensificar a experiência da obra a partir de uma "reconfiguração subjetiva"...

P: Agora estou achando melhor falar em "reconfiguração perspectiva".

M: Que seja. Se a crítica é uma reconfiguração perspectiva da obra, e se as próprias obras são também reconfigurações perspectivas dos textos dos quais partem ou mesmo da história das artes da cena, então qual seria a diferença entre crítica e criação?

P: Taí uma questão que não sei responder.

M: A crítica como uma forma de arte? Estupefaciente, meu caro!

P: Não que autoria importe, mas a ideia não é minha. Os românticos já diziam que "a poesia só pode ser criticada pela poesia". E Lukács, antes de ficar gagá, escreveu um texto belíssimo "sobre a essência e a forma do ensaio" que diz exatamente que "o ensaio é uma forma de arte".

M: Mas isso significaria que um texto crítico...

$\mathrm{P}$ : um ensaio...

M: ... precisa ter a mesma autonomia de uma obra de arte. Essa ideia acho mais difícil de absorver. Faz sentido ler uma crítica de um espetáculo que não vimos nem pretendemos ver?

P: Por que não faria?

M: Ué, porque aí o leitor não teria condições de dialogar com o crítico, se entendi bem quando mais cedo você disse que a crítica era também uma forma de diálogo.

P: Bom você ter falado isso. Essa é uma outra diferença importante entre uma crítica e um juízo sobre a arte, esses papéis de bala. Na verdade, quando o objetivo é consumir a arte, talvez não faça mesmo sentido ler um texto sobre uma obra que a gente não pretende "comprar". Mas o ensaio crítico, a rigor, não é um texto sobre uma obra, é muito mais um texto a partir de uma obra, que nos leva a pensar em questões que largamente a transcendem. Os românticos, sempre eles, falam em infinitização, na tarefa de mostrar as infinitas possíveis relações entre uma obra e outras obras, entre uma obra e a 
história, entre uma obra e as questões sociais, políticas e filosóficas mais amplas. Partindo sempre, é claro, de uma análise imanente de forma da obra, de uma reconfiguração perspectiva de seus elementos, de uma atenção às suas mínimas inflexões formais. A obra como microcosmo contém o macrocosmo, expressa-o de uma maneira singular. A obra como mônada, disse o Benjamin. Isso não tem nada a ver com a "teoria do reflexo" do Lukács gagá. A crítica opera de dentro para fora, e não de fora para dentro. Descobre na própria obra o mundo fora dela, em vez de projetar na obra informações (biográficas, estéticas, culturais) que o crítico teria obtido antes, independentemente de sua convivência com a obra - no Google, talvez. O Barthes, naquele mesmo texto, diz uma outra coisa muito bonita. Lê aí embaixo de novo. ${ }^{3}$

Pausa enquanto Mori lê.

M: Do caralho! Que ideia bonita essa de que "a crítica não é uma 'homenagem' à verdade do passado, ou à verdade do 'outro', ela é construção da inteligência do nosso tempo".

P: Também acho.

M: Engraçado...

P: O quê?

M: Tudo o que você me disse hoje é quase o oposto do que eu entendia antes como sendo crítica. Quando pensava em crítica, pensava em algo bastante dogmático, muito impressionista e fundamentalmente negativo. Em português, criticar não é normalmente o mesmo que "falar mal de"? E, curiosamente, todas as palavras que você usou para definir a crítica são essencialmente positivas, ou propositivas: integração, intensificação, potencialização, infinitização, reconfiguração, autonomia, coautoria, método do inacabável acabamento, construção da inteligência do nosso tempo...

P: Todas essas palavras são roubadas dos românticos... Já leu aquele livro do Benjamin sobre "O conceito de crítica de arte do romantismo alemão"? Quem não ler esse livro, não tenho a menor dúvida, vai direto para o inferno. (Risos.)

M: Vou ler, pode deixar. Tomara que esteja traduzido em japonês. Mas e o aspecto negativo da crítica, será que não é importante também? A construção da inteligência do nosso tempo não implica, e mesmo exige, recusar e denunciar as porcarias da indústria cultural que obstruem a emancipação dos espectadores e aprofundam essa visão de que tudo tem que ser mercadoria? 
P: Tenho discutido muito essa questão lá no meu curso sobre "A arte da crítica". Os românticos têm um princípio bem interessante: o da não-criticabilidade do que é ruim. Tudo o que está abaixo da crítica só merece, deles, o silêncio ou a destruição irônica. Como só gosto de escrever sobre os espetáculos que dialogam comigo, que me dão a sentir e pensar coisas antes desconhecidas ou não formuladas, no meu próprio trabalho tendo a seguir fielmente esse princípio. Afinal, não tendo nenhuma vontade de servir de "guia de consumo", por que perderia meu tempo falando daquilo que, pelo menos para mim, não é relevante?

M: Nesse caso, a razão seria menos estética ou existencial que política: assumir uma posição nessa guerrilha cultural...

P: Sinceramente, acho que silenciar sobre o que está abaixo da crítica já é uma posição bem clara. Quando adotada coletivamente, como fazemos na Questão de Crítica, aquela revista com a qual colaboro, ela ganha ainda mais peso. Mas, pensando melhor, descobri duas coisas: a primeira é que, assim como toda obra de arte, também os ensaios críticos contêm em si uma negatividade constitutiva. Ao recortar a obra segundo este princípio unificador e não aquele - o crítico, para mim, é talvez mais açougueiro do que jardineiro, já que toda a sua arte consiste em encontrar o ponto de corte preciso, o ponto de corte exigido pela "carne do espetáculo", sendo que esta é inclusive a leitura mais potente da etimologia da palavra crítica, que vem do verbo krinein, separar, romper, fazer uma incisão -, ao realçar estes elementos e não aqueles, o crítico age como o artista. Também ele se apropria só do que Ihe interessa na história das formas e, ainda que indiretamente, recusa um monte de outras posições possíveis.

M: E qual é a segunda coisa que você descobriu?

P: Que a crítica, mais do que uma reconfiguração perspectiva, é uma reconfiguração prospectiva. A construção da inteligência do nosso tempo de que fala o Barthes está muito mais voltada para o futuro do que para o passado, para o que ainda não é mas pode vir a ser, do que para os condicionamentos que tendem a engessar o pensamento. Nesse sentido, em todo ensaio crítico, por mais positivo ou propositivo que seja, há também um momento de denúncia ou negação dos elementos (ou de certas articulações de elementos) que estorvam a realização do ideal da obra, elementos que, ao serem modificados, permitiriam que a obra adquirisse uma potência ainda maior.

\section{M: Isso não é o clichê de uma "crítica construtiva"?}

P: De certa forma sim, afinal todo clichê tem um fundo de verdade, dependendo de como o lemos. Neste caso, retomando a ideia de que a crítica é fundamentalmente um diálogo entre o espectador que vê a obra e o encenador que primeiro a vislumbrou, unidos pela busca desse inalcançável "ideal da obra", do qual não obstante é sempre possível nos aproximarmos mais e mais, eu diria, para concluir... Você já pediu a conta? 
M: Já está paga.

P: Obrigado, Mori, não precisava. Deixa eu dividir contigo.

M: Lá em Tóquio você me paga uns saquês.

P: Combinado.

M: Você diria para concluir...

P: Que, hoje em dia, penso a crítica como uma carta aberta aos realizadores de uma obra, sobretudo ao encenador, responsável pela escolha de seu "princípio unificador". Neste sentido, gosto muito de ler o famoso "Ensaio como forma", do Adorno, como uma teoria das correspondências e do diálogo ainda possível em nosso tempo. O ensaio como forma outra coisa não é que o ensaio como carta...

M: E por que você escreveria cartas para alguns encenadores e não para outros?

P: Por gratidão. Em larga medida, a crítica para mim é o pagamento de uma dívida de gratidão. Dá uma olhada na epígrafe dessa conversa que você vai entender.

M: Conversa com epígrafe?! Tu é doido!

Pausa para Mori ler a epígrafe.

M: (Sorrindo com os olhos bem apertados, não se sabe se por influxo da origem nipônica ou das caipirinhas de caju.) Por tudo o que você me disse, diria mais. Lembra quando o Stendhal escreveu que "a arte contém sempre uma promessa de felicidade"? Por mais que, como ator, me custe dizer isso, acho que essa crítica de que você falou hoje é tão importante quanto a própria produção de espetáculos para realizar essa promessa.

P: Que bom que você me entende. Obrigado, meu amigo.

* Patrick Pessoa é professor adjunto do Departamento de Filosofia da UFF.

* Este texto foi publicado originalmente no livro 30 Encontro Questão de Crítica (Rio de Janeiro: Sette Letras, 2016), organizado por Daniele Avila Small e Dinah de Oliveira. Como ele serviu de ponto de partida para os ensaios dos professores Cíntia Vieira da Silva e Bernardo Barros Coelho de Oliveira, publicados neste número especial da Viso, decidi republicá-lo aqui na íntegra.

${ }^{1}$ BARTHES, R. "O que é a crítica". In: Crítica e verdade. São Paulo: Perspectiva, 2013, p. 161: "Se a crítica é apenas uma metalinguagem, sua tarefa não é descobrir 'verdades', mas 'validades'. [...] As regras a que está sujeita a linguagem literária não concernem a conformidade dessa linguagem com o real [...]. A crítica não consiste em dizer se Proust falou certo; [...] seu papel é unicamente 
elaborar ela mesma uma linguagem cuja coerência, cuja lógica e, para dizer tudo, cuja sistemática possa recolher ou, melhor ainda, 'integrar' (no sentido matemático da palavra) a maior quantidade possível de linguagem proustiana [...]. A tarefa da crítica é puramente formal: [...] consiste em ajustar, como um bom marceneiro que aproxima apalpando 'inteligentemente' duas peças de um móvel complicado, a linguagem que the fornece a sua época (existencialismo, marxismo, psicanálise) à linguagem, isto é, ao sistema formal de constrangimentos lógicos elaborados pelo próprio autor segundo sua própria época. A prova da crítica não é de ordem 'alética' (não depende da verdade), pois o discurso crítico nunca é mais do que tautológico: ele consiste finalmente em dizer com atraso [...]; a prova crítica, se ela existe, depende de uma aptidão não para descobrir a obra interrogada, mas ao contrário para cobri-la o mais completamente possível com sua própria linguagem".

2 SCHELLING, F. W. J. v. Sistema del idealismo transcendental. Barcelona: Anthropos, 1988, p. 102: "Do mesmo modo como o homem, sob o efeito da fatalidade, não realiza o que ele quer ou intenciona, mas o que ele tem de realizar através de um destino incompreensível, parece ao artista, na observação daquilo que é o propriamente objetivo na sua produção, por mais cheio de intenção que esteja, estar sob o efeito de um poder que o separa de todos os outros homens e o coage a exprimir ou apresentar o que ele próprio não penetra inteiramente, e cujo sentido é infinito. [...] Assim ocorre com toda obra de arte verdadeira, na medida em que ela é passível de uma interpretação infinita, como se houvesse nela uma infinitude de intenções que nunca se pode dizer se estava posta no próprio artista ou se antes repousava meramente na obra de arte".

${ }^{3}$ BARTHES, R. Op. Cit., p. 163. "o crítico não tem de reconstituir a mensagem da obra, mas somente seu sistema. [...] É com efeito ao reconhecer que ela não é mais do que uma metalinguagem que a crítica pode ser, de modo contraditório mas autêntico, ao mesmo tempo objetiva e subjetiva, histórica e existencial, totalizante e liberal. Pois, por um lado, a linguagem que cada crítico escolhe falar não lhe desce do céu, ela é alguma das linguagens que sua época Ihe propõe, ela é objetivamente o termo de um certo amadurecimento histórico do saber, das ideias, das paixões intelectuais, ela é uma necessidade; e por outro lado essa linguagem necessária é escolhida por cada crítico em função de uma certa organização existencial, como o exercício de uma função intelectual que lhe pertence particularmente, exercício no qual ele põe toda a sua 'profundidade', isto é, suas escolhas, seus prazeres, suas resistências, suas obsessões. Assim pode travar-se, no seio da obra crítica, o diálogo de duas histórias e de duas subjetividades, as do autor e as do crítico. Mas esse diálogo é egoisticamente todo desviado para o presente: a crítica não é uma 'homenagem' à verdade do passado, ou à verdade do 'outro', ela é construção da inteligência do nosso tempo". 